\title{
Mutants of Streptomyces roseosporus that express enhanced recombination within partially homologous genes
}

\author{
Thomas J. Hosted and Richard H. Baltz \\ Author for correspondence: Richard H. Baltz. Tel: +1 317276 5179. Fax: +1 3172769086. \\ e-mail: baltz_richard_h@lilly.com
}

Lilly Research Laboratories, A Division of Eli Lilly and Company, Indianapolis, IN 46285, USA

\begin{abstract}
Streptomyces roseosporus mutants that express enhanced recombination between partially homologous (homeologous) sequences were isolated by selection for recombination between the bacteriophage $\phi$ C31 derivative KC570 containing the Streptomyces coelicolor glucose kinase (glk) gene and the $S$. roseosporus chromosome. The frequencies of homeologous recombination in the ehr mutants were determined by measuring the chromosomal insertion frequencies of plasmids containing $S$. coelicolor gInA or whiG genes. 5 . roseosporus ehr mutants showed $10^{2}$ - to $10^{4}$-fold increases in homeologous recombination relative to Ehr ${ }^{+}$strains, but no increase in homologous recombination. Southern hybridization analysis revealed single unique sites for the insertion of each of the plasmids, and the crossovers occurred in frame and in proper translational register, yielding functional chimeric $g \ln A$ and whig genes.
\end{abstract}

Keywords: Streptomyces roseosporus, homeologous recombination, transposition mutagenesis, glutamine synthetase, sporulation sigma factor

\section{INTRODUCTION}

Homologous recombination by conjugation and by protoplast fusion is well documented in many streptomycetes (Chater \& Hopwood, 1983; Baltz \& Matsushima, 1983). Homeologous recombination (i.e. between partially homologous sequences) also occurs in different species of Streptomyces, but at greatly reduced frequencies relative to homologous recombination (Lomovskaya et al., 1977; Schlegel \& Fleck, 1980; Mazieres et al., 1981; Baltz \& Matsushima, 1983; Chater \& Bruton, 1983; Gomi et al., 1984). Homeologous recombination has been used to generate recombinants to produce novel antibiotics (Schlegel \& Fleck, 1980; Gomi et al., 1984), but the low frequencies of recombination have limited the implementation of this methodology in antibiotic discovery.

Homeologous recombination occurs at low frequencies between Escherichia coli and Salmonella typhimurium, which share about $80 \%$ nucleotide sequence identity. However,

Abbreviations: $C T A B$, cetyltrimethylammonium bromide; GS, glutamine synthetase.

The GenBank accession numbers for the nucleotide sequences reported in this paper are U57630 (chimeric glnA), U57631 (chimeric whiG), U58138 (S. roseosporus $g \ln A$ ) and U58281 (S. roseosporus whiG).
S. typhimurium strains defective in methyl mismatch repair form recombinants by conjugation with $E$. coli at $\sim 1000$ fold higher frequencies than strains proficient in mismatch repair (Rayssiguier et al., 1989; Matic et al., 1994; Worth et al., 1994). Furthermore, a mutant defective in uvrDencoded helicase activity showed enhancement in homologous and homeologous recombination (Feinstein \& Low, 1986; Rayssiguier et al., 1989). Zahrt et al. (1994) have also shown that the barrier to homeologous recombination between $S$. typhimurium and Salmonella typhi in transductional crosses is mismatch repair. In Saccharomyces cerevisiae, mismatch repair also acts as a barrier to homeologous recombination (Selva et al., 1995). Since mismatch repair is observed in other prokaryotes (Claverys \& Lacks, 1986; Le et al., 1993), yeast (Reenan \& Kolodner, 1992; Selva et al., 1995) and human cells (Fishel et al., 1993), we reasoned that mismatch repair is likely to be expressed by streptomycetes, and that mutation in mismatch repair genes might cause elevated homeologous recombination.

Here we describe the isolation of Streptomyces roseosporus mutants that express enhanced homeologous recombination but not enhanced homologous recombination, and show that homeologous recombination occurs within genes in the correct register to produce functional hybrid proteins. 
Table 1. Bacterial strains, plasmids and phage

\begin{tabular}{|c|c|c|}
\hline Strain or plasmid & Relevant characteristics & Source \\
\hline \multicolumn{3}{|l|}{ E. coli strains } \\
\hline S17-1 & Contains RP4 integrated in chromosome & Simon et al. (1983) \\
\hline XL1-blue MFR' & $\begin{array}{l}\Delta(m c r A) 183 \Delta(\operatorname{mcr} C B-h s d S M R-m r r) 173 \text { end } A 1 \\
\text { supE44 thi-1 rec } A 1 \text { gyr } A 96 \text { rel } A 1 \text { lac } \\
{\left[\mathrm{F}^{\prime} \text { pro } A B \text { lac }{ }^{q} Z \Delta M 15 \operatorname{Tn} 10\left(\mathrm{Tet}^{\mathrm{r}}\right)\right]}\end{array}$ & Stratagene \\
\hline \multicolumn{3}{|c|}{ S. roseosporus strains } \\
\hline A21978.6 & Wild-type, produces daptomycin & ATCC 31568 \\
\hline TH101 & A21978.6[chr:: Tn5099-10]ebr-1 & This work \\
\hline TH104 & A21978.6[chr:: Tn5099-10]ebr-2 & This work \\
\hline TH109 & A21978.6[chr:: Tn5099-10]ehr-3 & This work \\
\hline TH114 & A21978.6[chr:: $\operatorname{Tn} 5099-10] e b r-5$ & This work \\
\hline TH116 & A21978.6[chr:: Tn5099-10]ebr-6 & This work \\
\hline TH117 & A21978.6[chr::Tn5099-10]ehr-7 & This work \\
\hline TH119 & A21978.6[chr:: $\operatorname{Tn} 5099-10]$ & This work \\
\hline TH121 & A21978.6[chr:: Tn5099-10]ebr-8 & This work \\
\hline TH122 & A21978.6[chr:: Tn5099-10]ehr-9 & This work \\
\hline TH131 & A21978.6[chr::Tn5099-10] & This work \\
\hline TH134 & A21978.6[chr:: $\operatorname{Tn} 5099-10]$ & This work \\
\hline TH135 & A21978.6[chr:: $\operatorname{Tn} 5099-10]$ & This work \\
\hline TH101G & TH101::pRHB501 & This work \\
\hline TH104W & TH104::pRHB503 & This work \\
\hline TH104G1 & TH104::pRHB501 & This work \\
\hline TH104G2 & TH104::pRHB501 & This work \\
\hline TH104W1 & TH104::pRHB503 & This work \\
\hline TH109G & TH109::pRHB501 & This work \\
\hline TH109W & TH109::pRHB503 & This work \\
\hline TH114G & TH114::pRHB501 & This work \\
\hline TH114W & TH114::pRHB503 & This work \\
\hline TH116W & TH116::pRHB503 & This work \\
\hline TH119G & TH119::pRHB501 & This work \\
\hline TH119W & TH119::pRHB503 & This work \\
\hline TH122G & TH122::pRHB501 & This work \\
\hline TH131G & TH131::pRHB501 & This work \\
\hline TH134W & TH134::pRHB503 & This work \\
\hline TH135W & TH135::pRHB503 & This work \\
\hline TH148 & $\mathrm{A} 21978.6 \mathrm{Sm}^{\mathrm{R}}$ & $\begin{array}{l}\text { T. Hosted \& R. Baltz, } \\
\text { unpublished }\end{array}$ \\
\hline TH161 & $\mathrm{TH} 184 \mathrm{~g} \ln A:: \mathrm{Hm}^{\mathrm{R}}$ & $\begin{array}{l}\text { T. Hosted \& R. Baltz, } \\
\text { unpublished }\end{array}$ \\
\hline TH503D & TH104::pRHB503 & This work \\
\hline TH503E & TH104::pRHB503 & This work \\
\hline TH503F & TH134::pRHB503 & This work \\
\hline SRG & A21978.6::pRHB501 & This work \\
\hline \multicolumn{3}{|l|}{ Plasmids/phage } \\
\hline pBluescript II KS ${ }^{-}$ & $A p^{\mathrm{k}}$, ColE1 $r e p$ & Strategene \\
\hline PCRII & $3.9 \mathrm{~kb}$ TA cloning vector & Invitrogen \\
\hline$\phi \mathrm{KC} 570$ & $\mathrm{c}^{+} \Delta a t t P:: t s r:: v p b:: g l k$ & Fisher et al. (1987) \\
\hline pKC1139 & repts oriT & Bierman et al. (1992) \\
\hline pRHB501 & $8.8 \mathrm{~kb}, \mathrm{pKC} 1139$ containing $S$. coelicolor gln $A$ & This work \\
\hline pRHB503 & $8.7 \mathrm{~kb}, \mathrm{pKC} 1139$ containing $S$. coelicolor whiG & This work \\
\hline pRHB534 & $\begin{array}{l}\text { pCRII containing } 1.46 \mathrm{~kb} S \text {. roseosporus gln } A \\
\text { PCR fragment cloned in TA cloning site }\end{array}$ & This work \\
\hline
\end{tabular}


Table 1. (cont.)

\begin{tabular}{|c|c|c|}
\hline Strain or plasmid & Relevant characteristics & Source \\
\hline pRHB685 & $\begin{array}{l}8.0 \mathrm{~kb}, \mathrm{pKC} 1139 \text { containing } S . \text { roseosporus } \\
g \ln A\end{array}$ & This work \\
\hline pRHB596 & $\begin{array}{l}4.2 \mathrm{~kb} \text { derivative of } \mathrm{pRHB} 501 \text { containing } \\
\text { chimeric } g \ln A\end{array}$ & This work \\
\hline pRHB597 & $\begin{array}{l}11 \cdot 0 \mathrm{~kb} \text { derivative of pRHB503 containing } \\
\text { chimeric whiG }\end{array}$ & This work \\
\hline pDELTAI & Tet $^{\mathrm{R}} \mathrm{Ap}^{\mathrm{R}} \mathrm{Kan}^{\mathrm{R}}$ ColE1 rep & BRL \\
\hline pLEW3 & $\begin{array}{l}\text { pIC19H containing the } S \text {. coelicolor } \operatorname{gln} A \text { on a } \\
2.3 \mathrm{~kb} \text { SacI fragment }\end{array}$ & Wray \& Fisher (1988) \\
\hline mp18::wbiG & $\begin{array}{l}\text { MP18 containing } S \text {. coelicolor } w h i G \text { on a } 2.0 \mathrm{~kb} \\
\text { NcoI fragment }\end{array}$ & Chater et al. (1989) \\
\hline pRHB520 & $\begin{array}{l}\text { pBluescript II } \mathrm{KS}^{-} \text {containing } 12 \mathrm{~kb} \text { Pst } \mathrm{I} \\
\text { fragment with Tn } 5099-10 \text { and flanking DNA } \\
\text { from TH111 }\end{array}$ & This work \\
\hline pRHB521 & $\begin{array}{l}\text { PDELTAI containing a } 12 \mathrm{~kb} M l u \text { fragment } \\
\text { with Tn } 5099-10 \text { and flanking DNA from } \\
\text { TH119 }\end{array}$ & This work \\
\hline pRHB522 & $\begin{array}{l}\text { pBluescript II } \mathrm{KS}^{-} \text {containing a } 6 \mathrm{~kb} \text { ClaI } \\
\text { fragment with Tn } 5099-10 \text { and flanking DNA } \\
\text { from TH129 }\end{array}$ & This work \\
\hline pRHB523 & $\begin{array}{l}\text { pBluescript II KS containing a } 14 \mathrm{~kb} \mathrm{KpnI} \\
\text { fragment with Tn } 5099-10 \text { and flanking DNA } \\
\text { from TH104 }\end{array}$ & This work \\
\hline pRHB524 & $\begin{array}{l}\text { PDELTAI containing a } 11 \mathrm{~kb} M l u \text { fragment } \\
\text { with Tn } 5099-10 \text { and flanking DNA from } \\
\text { TH122 }\end{array}$ & This work \\
\hline
\end{tabular}

\section{METHODS}

Bacterial strains, bacteriophages and plasmids. These are listed in Table 1.

Media and growth conditions. S. roseosporus strains were grown in CSM liquid medium (30 g Trypticase soy broth, $3 \mathrm{~g}$ yeast extract, $2 \mathrm{~g} \mathrm{MgSO}_{4}, 5 \mathrm{~g}$ glucose and $4 \mathrm{~g}$ maltose per litre deionized $\mathrm{H}_{2} \mathrm{O}$ ) at $29^{\circ} \mathrm{C}$ or $39^{\circ} \mathrm{C}$ and were fragmented into individual colony-forming units by homogenization followed by ultrasonic vibration as described previously (Baltz, 1978). Colony-forming units were determined by plating diluted mycelial fragments in nutrient soft agar overlays (Cox \& Baltz, 1984) on B agar (Solenberg \& Baltz, 1991), and incubating at $29^{\circ} \mathrm{C}$ or $39^{\circ} \mathrm{C}$ for $6 \mathrm{~d}$ then counting. E. coli strains were grown in either TY medium (Sambrook et al., 1989) or Circlegrow medium (Bio101). Antibiotics were added to appropriate media for streptomycete strains at $30 \mu \mathrm{g} \mathrm{ml}^{-1}$ for apramycin (Am), $200 \mu \mathrm{g} \mathrm{m} l^{-1}$ for hygromycin $(\mathrm{Hm}), 50 \mu \mathrm{g} \mathrm{ml}^{-1}$ for nalidixic acid $(\mathrm{Nal})$ and $50 \mu \mathrm{g} \mathrm{ml}^{-1}$ for thiostrepton (Ts). For E. coli strains, antibiotics were added to agar at $100 \mu \mathrm{g} \mathrm{ml}^{-1}$ for $\mathrm{Am}$ or $\mathrm{Hm}$.

Glutamine synthetase (GS) assay. S. roseosporus strains were grown in CSM medium to stationary phase, permeabilized by cetyltrimethylammonium bromide (CTAB) as described by Penyige et al. (1994), and GS activity was determined using the $\gamma$-glutamyltransferase assay described by Bender et al. (1977). One unit of specific activity equals $1 \mathrm{mmol} \gamma$-glutamylhydroxamate formed $\min ^{-1}$ ( $\mathrm{mg}$ protein $)^{-1}$ at $37^{\circ} \mathrm{C}$.

DNA techniques. Standard methods were used for plasmid isolation, restriction enzyme digestion, random priming and Southern hybridization analysis (Sambrook et al., 1989). Restriction endonucleases and other enzymes were used according to the manufacturer's recommendations. DNA fragments used for subcloning and radiolabelling were isolated from $0.8 \%$ SeaKem agarose (FMC) gels following electrophoresis using GenecleanII (Bio101). S. roseosporus genomic DNA was isolated as described by Hopwood et al. (1985). DNA sequence was determined using a Taq Dye Deoxy Terminator Cycle sequencing kit and a model 373A DNA sequencing system (Applied Biosystems).

Nucleotide sequence and data analysis. Derived amino acid sequences were analysed using the GCG package (version 8.0) (Devereux et al., 1984). Amino acid sequence homology searches were performed using the BLAST network service and nonredundant protein sequence databases (Altschul et al., 1990).

Transformation, electroporation, conjugation, transduction and transposition. Plasmids were introduced into E. coli XL1blue MFR' by electroporation using a BioRad Genepulser electroporator. Electrocompetent cells were prepared as described by Speyer (1990). E. coli S17-1 was transformed as described by Sambrook et al. (1989). Plasmids pRHB501 and pRHB503 were introduced into $S$. roseosporus strains by conjugation from $E$. coli $S 17-1$. S. roseosporus was grown from a frozen $\left(-70^{\circ} \mathrm{C}\right)$ stock in CSM medium for $16 \mathrm{~h}$, and $E$. coli was grown from a $1 \%(\mathrm{v} / \mathrm{v})$ inoculum in TY broth for $3-5 \mathrm{~h}$ at $37^{\circ} \mathrm{C}$. S. roseosporus mycelia were homogenized and mated in $1: 9,1: 1$ and $9: 1$ ratios $(100 \mu l$ total volume) with E. coli $\mathrm{S} 17-1$ containing the appropriate plasmid, and spread on $\mathrm{B}$ agar plates using a glass spreader. B agar plates were incubated for $15 \mathrm{~h}$ at $29^{\circ} \mathrm{C}$ and then overlaid with nutrient soft agat containing $\mathrm{Nal}$ and $\mathrm{Am}$ to give $50 \mu \mathrm{g} \mathrm{mi}^{-1}$ and $30 \mu \mathrm{g} \mathrm{m}^{-1}$ final bottom agar concentrations, respectively. Transconjugants appearing in 4-6 d were picked, homogenized and grown in CSM medium 
containing $50 \mu \mathrm{g} \mathrm{Nal} \mathrm{ml} l^{-1}$ and $30 \mu \mathrm{g} \mathrm{Am} \mathrm{m}{ }^{-1}$. S. roseosporus Tn5099-10 transposon libraries were constructed as previously described (Solenberg \& Baltz, 1994). A library of S. roseosporus Tn 5099-10 mutants was grown in CSM medium at $29^{\circ} \mathrm{C} ; 12 \mathrm{ml}$ $\left(\sim 1.2 \times 10^{9}\right.$ cells) were transduced with KC570 at a multiplicity of infection of about 1 and plated on B agar. The plates were overlaid with nutrient soft agar containing Ts to give a final bottom agar concentration of $50 \mu \mathrm{g} \mathrm{ml}^{-1}$. $\mathrm{Ts}^{\mathrm{R}}$ transductants arose in 3-5 d and were patched to B agar plates, homogenized and grown in CSM medium containing $250 \mu \mathrm{g} \mathrm{Ts} \mathrm{ml}^{-1}$ and $200 \mu \mathrm{g} \mathrm{Hm} \mathrm{ml}^{-1}$. Transductants were subsequently grown with $\mathrm{Hm}$ selection alone.

Plasmid constructions. Plasmids were constructed in E. coli strains as follows. A $2.3 \mathrm{~kb}$ HindIII fragment containing the $S$. coelicolor gln $A$ gene from pLEW3 (Wray \& Fisher, 1988) was ligated with HindIII-cleaved pKC1139 (Bierman et al., 1992) to give pRHB501. A $2 \cdot 2 \mathrm{~kb}$ EcoRI-HindIII fragment containing $S$. coelicolor whiG from mp18:: whiG (Chater et al., 1989) was ligated with pKC1139 digested with EcoRI and HindIII to yield pRHB503. DNA from strain TH104G1 containing pRHB501 inserted in the chromosome was digested with ClaI, and selfligated. Transformants were selected for $\mathrm{Am}^{\mathrm{R}}$ to yield pRHB596. DNA from TH104W 1 containing pRHB503 inserted in the chromosome was digested with $B g / I I$ and self-ligated. Transformants were selected for $\mathrm{Am}^{\mathrm{R}}$ to yield pRHB597. A $12 \mathrm{~kb}$ Pst I DNA fragment from TH111 that hybridized to radiolabelled Tn5099-10 was separated by gel electrophoresis and ligated to PstI-digested pBluescript II $\mathrm{KS}^{-}$. Transformants of E. coli XL1-blue MFR' containing 'Tn5099-10 and flanking chromosomal DNA were selected for $\mathrm{Hm}^{\mathrm{R}}$ to yield pRHB520. A $12 \mathrm{~kb} M l u \mathrm{I}$ DNA fragment from $\mathrm{TH} 119$ that hybridized to radiolabelled Tn5099-10 was isolated by gel electrophoresis and ligated to MluI-digested pDELTAI (BRL). Transformants of E. coli XL1-blue $\mathrm{MFR}^{\prime}$ were selected for $\mathrm{Hm}^{\mathrm{R}}$, yielding pRHB521. A $6 \mathrm{~kb}$ ClaI DNA fragment from TH129 that hybridized to radiolabelled Tn5099-10 was isolated by gel electrophoresis and ligated to ClaI-digested pBluescript II $\mathrm{KS}^{-}$. Transformants of $E$. coli XL1-blue MFR' were selected for $\mathrm{Hm}^{\mathrm{R}}$, yielding pRHB522. A $14 \mathrm{~kb} \mathrm{KpnI} \mathrm{DNA} \mathrm{fragment} \mathrm{from}$ TH104 that hybridized to radiolabelled $\operatorname{Tn} 5099-10$ was isolated by gel electrophoresis and ligated to $K p n I$-digested pBluescriptII $\mathrm{KS}^{-}$. Transformants of $E$. coli XL1-blue MFR' were selected for $\mathrm{Hm}^{\mathrm{R}}$, yielding pRHB523. A $11 \mathrm{~kb} M l u \mathrm{I}$ DNA fragment from TH122 that hybridized to radiolabelled $\operatorname{Tn} 5099-10$ was isolated by gel electrophoresis and ligated to $M l u I$-digested PDELTAI (BRL). Transformants of E. coli XL1-blue MFR' were selected for $\mathrm{Hm}^{\mathrm{R}}$, yielding pRHB524. A $1.46 \mathrm{~kb}$ fragment containing $S$. roseosporus $g \ln A$ was PCR-amplified from $S$. roseosporus chromosomal DNA using primers PR170 (5' GCTGAGATGCCGCCCACCAC 3') and PR171 (5' ACGCCGCCCGCCTGGAGGTA $3^{\prime}$ ) and ligated to pCRII (Invitrogen) to yield pRHB534. The $1.46 \mathrm{~kb} E c o$ RI fragment containing $g \ln A$ was ligated with EcoRI-digested pKC1139 to yield pRHB685.

\section{RESULTS}

\section{Selection for S. roseosporus ehr mutants}

We prepared a Tn5099-10 (Solenberg \& Baltz, 1994) transposition mutant library of $S$. roseosporus, introduced the bacteriophage $\phi \mathrm{C} 31$ derivative KC570 (Fisher et al., 1987 ) into the library, and screened for $\mathrm{Ts}^{\mathrm{R}}$ transductants.
Since KC570 contains no plasmid replication functions and lacks the $\phi \mathrm{C} 31$ att $P$ sequence, it can form recombinants only by inserting into the chromosome. KC570 contains the glk gene from $S$. coelicolor, so recombinants might be formed in $S$. roseosporus by homeologous recombination into the $S$. roseosporus glk gene. Several Ts ${ }^{R}$ transductants were obtained, and Southern analysis of transductants showed a single band that hybridized to the tsr gene (data not shown). Subsequently, transductants were grown with $\mathrm{Hm}$ selection alone, and hybridization to the tsr gene was lost, presumably due to loss of KC570 by recombinational excision and curing. Most of the putative $e b r$ mutants contained Tn5099-10 insertions in different sites in the chromosome, and four different confirmed $e b r$ mutants (strains TH104, TH119, TH122 and TH129; see below) contained Tn 5099-10 insertions in genes unrelated to mismatch repair or to other known recombination functions based upon DNA sequence analysis (data not shown). Thus the ebr mutants were probably due to spontaneous point mutations.

\section{Analysis of spontaneous mutation frequencies in S. roseosporus mutants}

Since mut $L$ and mutS mutants of E. coli and S. typhimurium express elevated spontaneous mutation rates, we tested many of the putative $e b r$ mutants for spontaneous mutation frequencies to rifamycin resistance $\left(\mathrm{Rif}^{\mathrm{R}}\right)$ and to streptomycin resistance $\left(\mathrm{Sm}^{\mathbf{R}}\right)$. Table 2 shows that none of a representative sample of mutants showed spontaneous mutation frequencies that deviated significantly from those of the $S$. roseosporus parent strain. Thus, spontaneous mutability was not associated with the apparent Ehr phenotype.

\section{Analysis of recombination frequencies by plasmid insertions}

We constructed two plasmids to directly measure homeologous recombination and one to measure homologous recombination in the $S$. roseosporus mutants. pRHB501 (Fig. 1, Table 1) contains the $S$. coelicolor gln $A$ gene inserted into $\mathrm{pKC} 1139$, a plasmid that has temperature sensitive (ts) replication functions for streptomycetes and ori $T$ for conjugal transfer from $E$. coli to streptomycetes. pRHB685 is similar to pRHB501 except that it has the $S$. roseosporus gln $A$ gene inserted in $\mathrm{pKC1139}$ (Table 1). pRHB503 is also a similar plasmid containing the $S$. coelicolor whiG gene (Fig. 2, Table 1). pRHB501 and pRHB503 were introduced into many different putative $e b r$ mutants of $S$. roseosporus by conjugation from $E$. coli S17-1. Transconjugants were grown in CSM medium at $29^{\circ} \mathrm{C}$ for $16 \mathrm{~h}$, sonicated, diluted, plated on $\mathrm{B}$ agar and incubated at $29^{\circ} \mathrm{C}$ and $39^{\circ} \mathrm{C}$. Recombinant frequencies were determined as the ratio of the number of colonies that grew at $39^{\circ} \mathrm{C}$ to the number that grew at $29^{\circ} \mathrm{C}$ in the presence of Am. Table 2 shows that most of the putative $e b r$ mutants gave recombinant frequencies of $10^{-5}$ to $10^{-4}$ with both plasmids. The $S$. roseosporus parental strain gave recombinant frequencies $10^{-7}$ or less. Similarly, two random Tn5099-10 transposition mutants, TH134 and 
Table 2. Spontaneous mutation and recombination frequencies in S. roseosporus strains

\begin{tabular}{|c|c|c|c|c|c|}
\hline \multirow[t]{2}{*}{ Strain } & \multicolumn{2}{|c|}{ Mutation frequency } & \multicolumn{3}{|c|}{ Recombination frequency } \\
\hline & $\operatorname{Rif}^{\mathbf{R}}$ & $S m^{R}$ & pRHB501 & pRHB503 & pRHB685* \\
\hline $\begin{array}{l}\text { A21978.6 } \\
\text { (wild-type) }\end{array}$ & $5 \times 10^{-8}$ & $1 \times 10^{-8}$ & $<1 \times 10^{-7}$ & $1 \times 10^{-7}$ & $3 \times 10^{-2} ; 4 \times 10^{-2}$ \\
\hline TH101 & $8 \times 10^{-8}$ & ND & $4 \times 10^{-5}$ & ND & ND \\
\hline TH104 & $7 \times 10^{-8}$ & $1 \times 10^{-8}$ & $7 \times 10^{-5}$ & $4 \times 10^{-5}$ & ND \\
\hline TH109 & $2 \times 10^{-8}$ & ND & $6 \times 10^{-5}$ & $6 \times 10^{-5}$ & ND \\
\hline TH114 & ND & ND & $4 \times 10^{-5}$ & $5 \times 10^{-6}$ & ND \\
\hline TH116 & $1 \times 10^{-7}$ & $2 \times 10^{-8}$ & $3 \times 10^{-4}$ & $9 \times 10^{-5}$ & $4 \times 10^{-3} ; 3 \times 10^{-3}$ \\
\hline TH117 & $6 \times 10^{-8}$ & $9 \times 10^{-9}$ & $7 \times 10^{-5}$ & $1 \times 10^{-5}$ & ND \\
\hline TH119 & $9 \times 10^{-9}$ & ND & $2 \times 10^{-4}$ & $1 \times 10^{-2}$ & ND \\
\hline TH121 & $4 \times 10^{-8}$ & $4 \times 10^{-9}$ & $2 \times 10^{-5}$ & $2 \times 10^{-5}$ & ND \\
\hline TH122 & $7 \times 10^{-8}$ & ND & $1 \times 10^{-3}$ & $3 \times 10^{-4}$ & $3 \times 10^{-3} ; 7 \times 10^{-3}$ \\
\hline TH131 & $3 \times 10^{-8}$ & $\mathrm{ND}$ & $2 \times 10^{-7}$ & $<1 \times 10^{-7}$ & ND \\
\hline TH134 & ND & ND & $<1 \times 10^{-7}$ & $<1 \times 10^{-7}$ & $2 \times 10^{-2} ; 9 \times 10^{-3}$ \\
\hline TH135 & ND & ND & $<1 \times 10^{-7}$ & $<1 \times 10^{-7}$ & ND \\
\hline
\end{tabular}

ND, Not determined.

* Recombination frequencies determined in two separate experiments.

TH135, gave recombinant frequencies of $<10^{-7}$. Only one of the putative ebr mutants, TH131, was not confirmed to give enhanced homeologous recombination by this procedure. Another mutant (TH119) gave an unusually high frequency of recombination with pRHB503, which is probably not due to homeologous recombination (see below). To confirm that the recombinants contained pRHB501 or pRHB503 inserted into the chromosome, $\mathrm{Am}^{\mathbf{R}}$ colonies were grown again in CSM broth plus Am at $30 \mu \mathrm{g} \mathrm{ml}^{-1}$. DNA was isolated, cleaved with HindIII, separated by agarose gel electrophoresis and analysed by Southern hybridization using pRHB501 or pRHB503 as probes. Fig. 1 shows that four individual transconjugants of strains TH101, TH109, TH114, TH119 and TH122 contained identical junction fragments and an internal pKC1139 fragment. Thus, all of the recombinants contained pRHB501 inserted into the same locus, presumably the $g \ln A$ gene. The three rare recombinants obtained with the $e h r^{+}$strains TH131 and $S$. roseosporus A21978.6 gave identical patterns, indicating that recombinants formed in $e b r$ mutants are identical to those formed in $e h r^{+}$strains.

Similarly, recombinants formed from strains carrying pRHB503 generally contained pRHB503 inserted into a unique locus, generating identical junction fragments (Fig. 2). Again, the rare recombinants formed in the $e b r^{+}$ strains TH134 and TH135 gave the same pattern as the $e b r$ mutants. The exception was strain TH119; this gave a totally different pattern, which included the $2 \cdot 3 \mathrm{~kb}$ intact $S$. coelicolor whiG gene. The original strain TH119 was probed with pCZA185, and shown to contain plasmid sequences from the transposon delivery vector (data not shown). DNA sequence analysis of pRHB521, Tn 5099-10 and flanking DNA from TH119 also confirmed that plasmid sequences were present (data not shown). Thus, the high frequency of recombination of pRHB503 in TH119 (10 ${ }^{-2}$; Table 2$)$ is probably due to homologous recombination across plasmid sequences rather than to homeologous recombination across whiG sequences.

We also tested two of the $e b r$ mutants and two control strains for homologous recombination within the $S$. roseosporus gln $A$ using plasmid pRHB685. The control strains A21978.6 and TH134 gave homologous recombination frequencies of 1 to $4 \times 10^{-2}$, about $10^{5}$-fold higher than the homeologous recombination frequencies observed with pRHB501 and pRHB503. The ebr mutants TH116 and TH122 gave homologous recombination frequencies of 3 to $7 \times 10^{-3}$. These values are within an order of magnitude of the homeologous recombination frequencies observed with pRHB501 containing the $S$. coelicolor $g \ln A$ gene. Interestingly, the homologous recombination frequencies were not enhanced in the ebr mutants, but reduced relative to controls. These data demonstrate that the $e h r$ mutants are defective in a repair or recombination system that normally interferes specifically with homeologous recombination.

\section{Analysis of crossover junctions in recombinants containing pRHB501 and pRHB503 inserted in the chromosome}

Chromosomal DNA from strain TH104G1, containing pRHB501 inserted in the chromosome, was cleaved with $C l a \mathrm{I}$, self-ligated and introduced into E. coli XL1-blue MFR' by electroporation. Am ${ }^{\mathbf{R}}$ transformants contained plasmid pRHB596, comprised of pRHB501 and DNA flanking the original plasmid insertion site (Fig. 1). Similarly, DNA from strain TH104W1 containing 
(a)

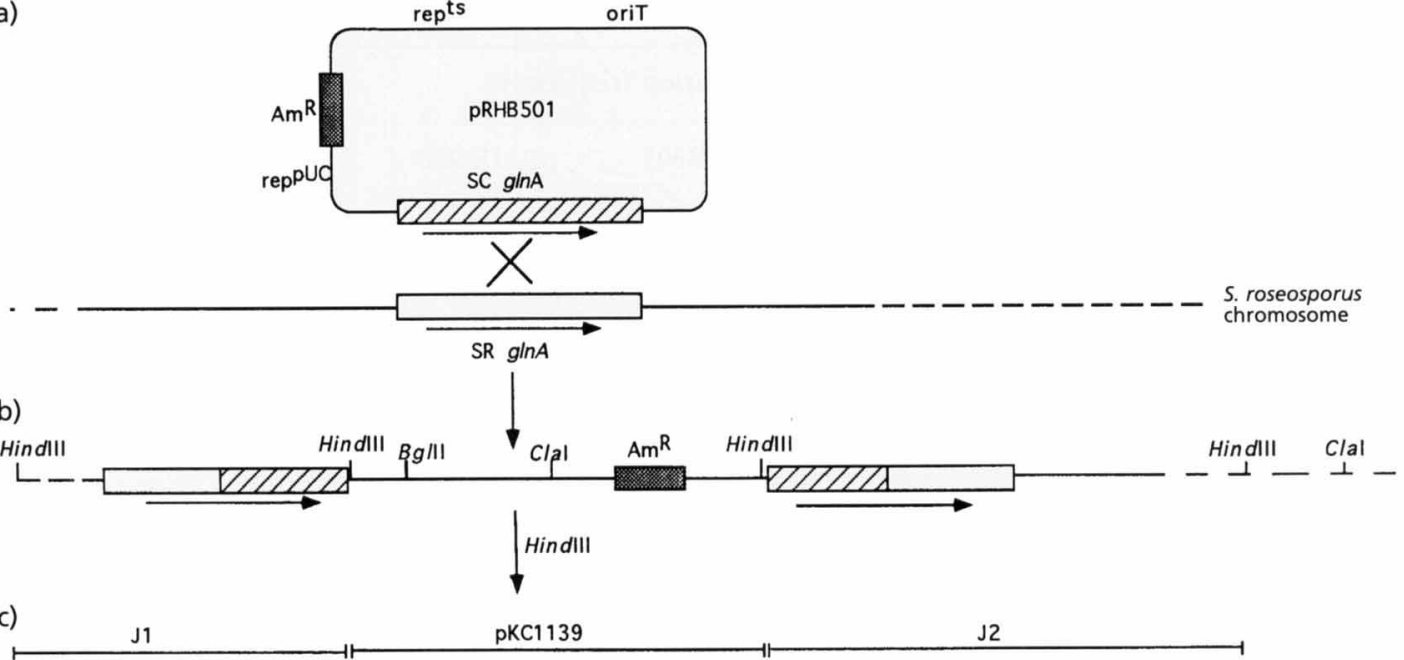

(d)

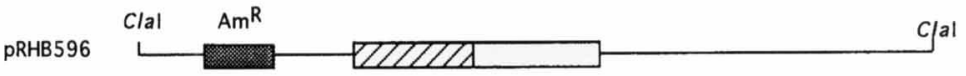

(e)
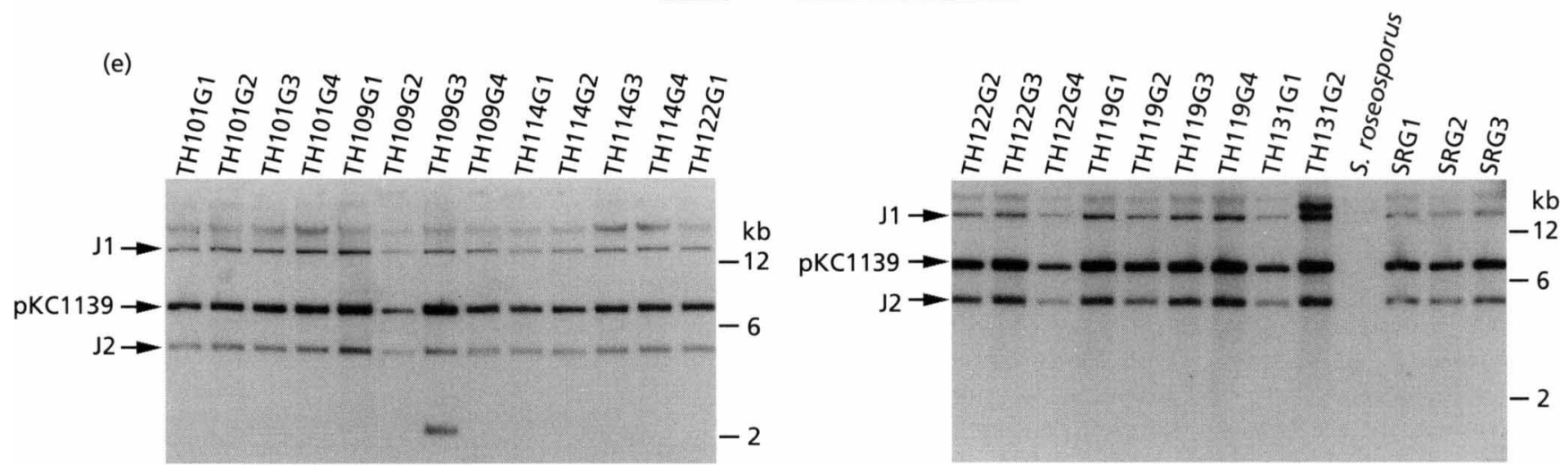

Fig. 1. Integration of pRHB501 into the $S$. roseosporus $g / n A$ gene and cloning of a $S$. roseosporus and $S$. coelicolor chimeric gInA junction fragment. (a) Map of pRHBS01 and the corresponding chromosomal region of $S$. roseosporus. SC $g \ln A$, S. coelicolor $g \ln A$; SR $g \ln A$, S. roseosporus $g \ln A$; rep pUC, pUC18 origin of replication; rep ${ }^{\text {ts }}$, streptomycete temperature-sensitive origin of replication; oriT, conjugation origin of transfer; $\mathrm{Am}^{\mathrm{R}}$, apramycin resistance; arrows indicate the direction of transcription. (b) Map of the crossover of pRHB501 into the $S$. coelicolor chromosome. (c) Junction fragments and pKC1139 fragment generated by digestion with HindIII (not to scale). (d) Map of pRHB596 containing a S. coelicolor and S. roseosporus chimeric g/nA gene prior to self-ligation. (e) Southern hybridization analysis of pRHB501 insertions into the S. roseosporus chromosome. The strains designated G1, G2, etc., represent independent insertions of pRHB501 in the parent strains (see Table 1). Chromosomal DNA was cleaved with HindIII, separated by agarose gel electrophoresis, blotted, and hybridized with radiolabelled pRHB501. Arrows indicate two crossover junction fragments (J1, J2), and a pKC1139 fragment.

pRHB503 was cleaved with BcIII, self-ligated, and introduced into $E$. coli XL1-blue MFR' by electroporation. $\mathrm{Am}^{\mathrm{R}}$ transformants contained plasmid pRHB597, comprised of pRHB503 and DNA flanking the insert (Fig. 2).

Portions of the putative recombinant $g \ln A$ and $w b i G$ genes were sequenced, and compared to the $\operatorname{gln} A$ and whiG sequences of $S$. coelicolor. Fig. 3(a) shows that the $g \ln A$ gene present in plasmid pRHB596 is chimeric. The left end of the chimeric gene from position 123 to 281 has $100 \%$ identity to the $S$. roseosporus sequence and $87 \%$ identity to the $S$. coelicolor sequence, whereas the right end from position 270 to 372 has $92 \%$ identity to the $S$. roseosporus sequence and $100 \%$ identity to the $S$. coelicolor sequence. This indicates the crossover of pRHB596 into the chromosome occurred between positions 1198 and 2008 within the $S$. roseosporus $g \ln A$ gene. These data confirmed that the crossover in strain TH104G1 occurred within the $g \ln A$ structural gene, in frame, and in translational register (Fig. $3 \mathrm{~b}$ ) with the $g \ln A$ gene of $S$. coelicolor.

Fig. 4(a) shows the sequence analysis of the chimeric whiG gene in plasmid pRHB597. In this case, there are two areas of $100 \%$ identity to the $S$. coelicolor sequence from positions 201 to 266 and 418 to 552 of the chimeric 
(a)

(b)

(c)

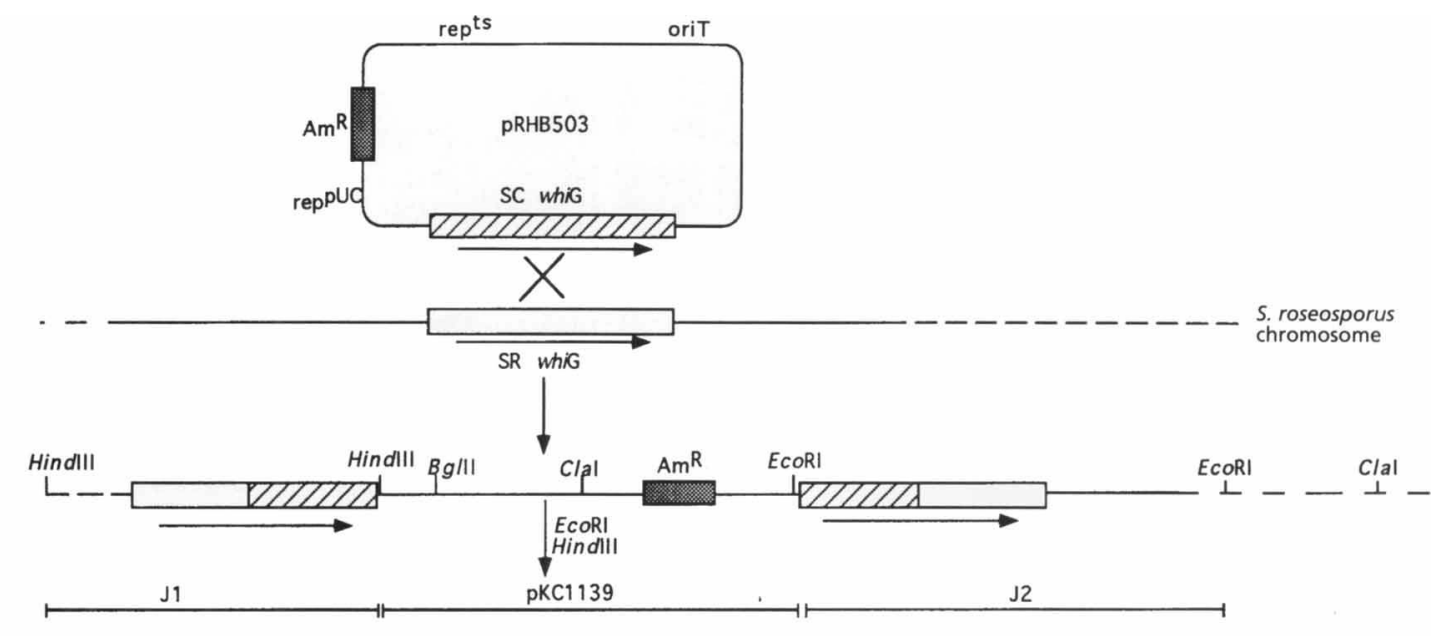

(d)

(e)

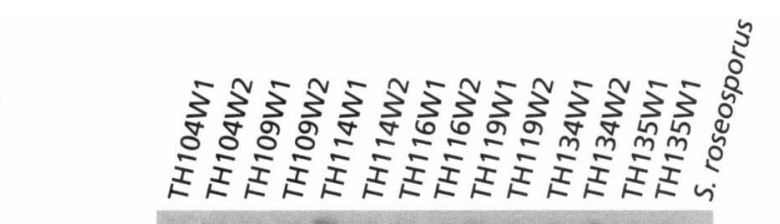

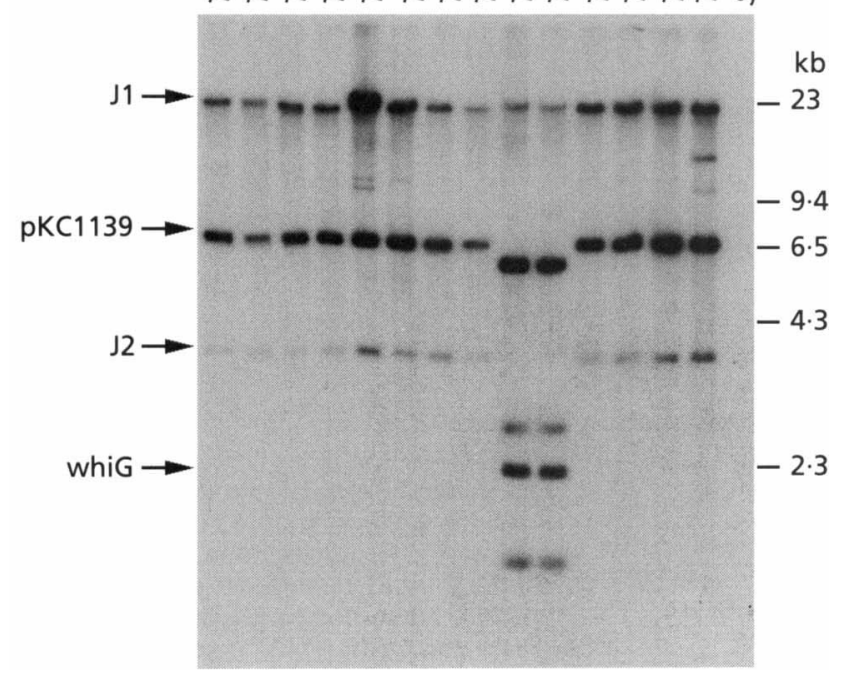

Fig. 2. Integration of pRHBSO3 into the $S$. roseosporus whiG gene and cloning of the $S$. roseosporus and $S$. coelicolor chimeric whiG junction fragment. (a) Map of pRHB503 and the corresponding chromosomal region of $S$. roseosporus. SC whiG, S. coelicolor whiG; SR whiG, S. roseosporus whiG; other details as for Fig. 1(a). (b) Map of the crossover of pRHB503 into the $S$. coelicolor chromosome. (c) Junction fragments and pKC1139 fragment generated by digestion with HindIII and EcoRI (not to scale). (d) Map of pRHB597 containing S. coelicolor and S. roseosporus chimeric whiG prior to self-ligation. (e) Southern hybridization analysis of pRHB503 insertions into the $S$. roseosporus chromosome. The strains designated $\mathrm{W} 1, \mathrm{~W} 2$, etc., represent independent insertions into the parent strains (see Table 1). Chromosomal DNA was cleaved with EcoRI and HindIII, separated by agarose gel electrophoresis, blotted, and hybridized with radiolabelled pRHB503. Arrows indicate two crossover junction fragments (J1, J2), a pKC1139 fragment, and a whiG fragment from a crossover in a pKC1139 sequence rather than in a whiG sequence in strain $\mathrm{TH} 119 \mathrm{~W}$. sequence. There are also two areas of $100 \%$ identity to the S. roseosporus sequence from positions 253 to 427 and 447 to 550 . Similar to the above results with pRHB596, each region with $100 \%$ identity to either $S$. roseosporus or $S$. coelicolor shows less than $100 \%$ identity to the alternate sequence. These results indicate that the chimeric whiG gene was generated by three crossover events within a span of about 200 base pairs. As with the chimeric $g \ln A$ gene, these recombinations occurred in frame and in proper translation register (Fig. 4b).

\section{Functional analysis of the chimeric $g \ln A$ and whiG gene(s)}

Streptomycetes express two glutamine synthetase (GS) activities, GSI and GSII (Behrmann et al., 1990; Kumada et al., 1990). GSI activity, encoded by the $g \ln A$ gene (Fisher \& Wray, 1989; Wray \& Fisher, 1988), is heat stable, whereas GSII activity is heat labile.

To determine if chimeric $g \ln A$ gene(s) generated by homeologous recombination are functional, we carried out GS assays with CTAB-permeabilized $S$. roseosporus strains before and after heat treatment. Table 3 shows that the ebr mutant TH104 and a random Tn5099 insertion mutant TH131 express primarily heat-stable GS activity. S. roseosporus TH104G1 and TH104G2, each containing two copies of chimeric $g \ln A$ genes, expressed about twice as much GS activity as TH104 or TH131 before heat treatment, and comparable activities after heat treatment. Since a substantial amount of GS activity was retained after heat treatment, at least one of the chimeric $g \ln A$ 
(a)

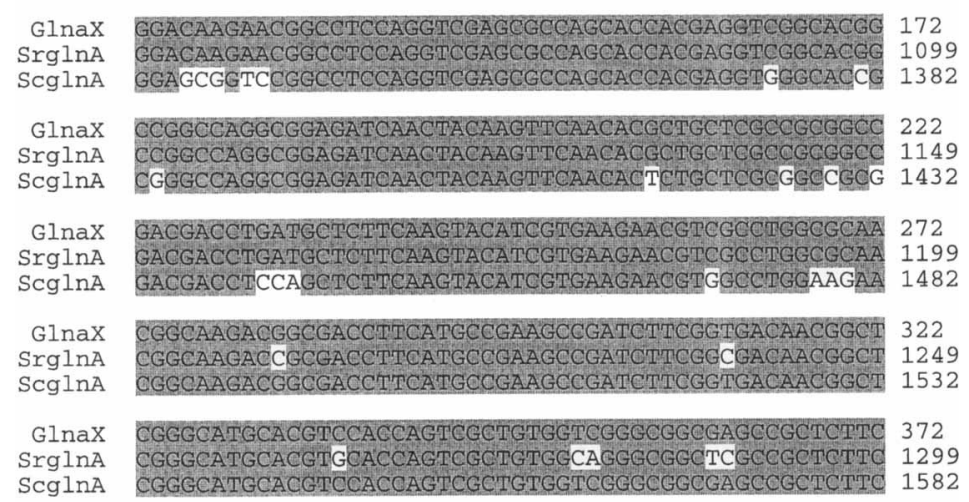

(b)

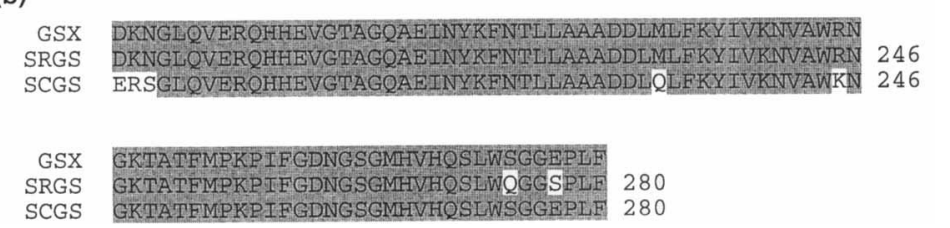

Fig. 3. Analysis of a segment of a chimeric ginA gene in pRHB596. (a) Homology between the nucleotide sequence of the chimeric glnA gene from pRHB596 (GlnAX) and the corresponding $g \ln A$ sequence of S. roseosporus (SrglnA) and S. coelicolor (ScglnA). (b) Homology between the predicted amino acid sequence of the chimeric GS (GSX) and the corresponding amino acid sequence of $S$. roseosporus GS (SRGS) and S. coelicolor GS (SCGS). Nucleotide and amino acids with shading indicate identity with the corresponding chimeric sequence. Nucleotide and amino acid positions are indicated to the right of the corresponding sequences.

(a)

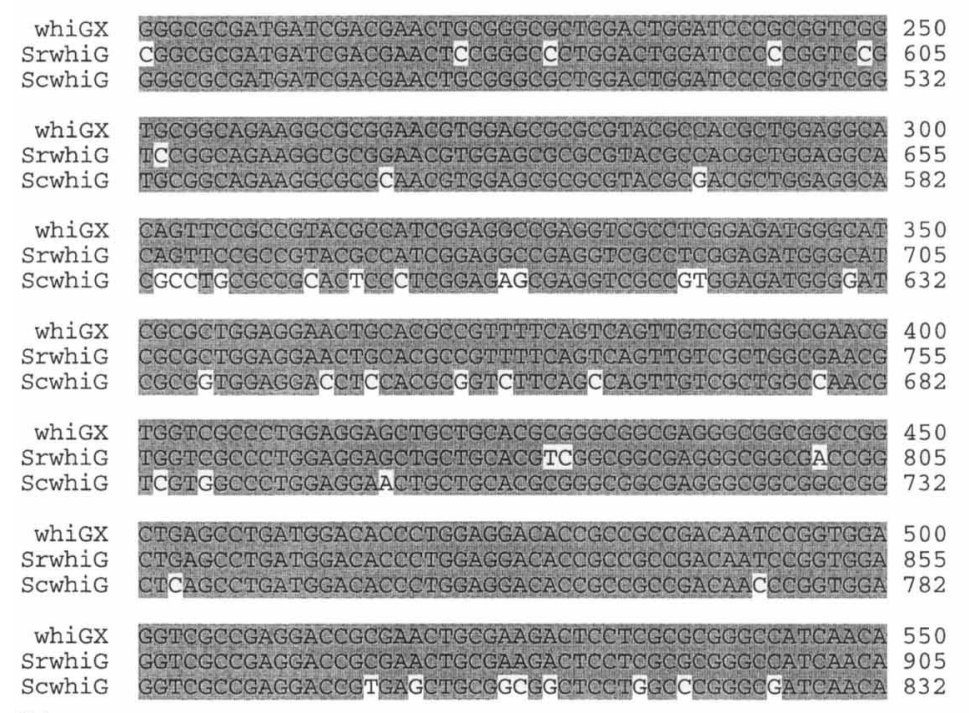

(b)

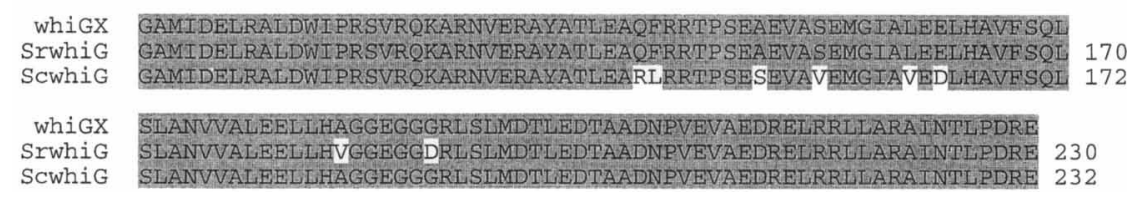

\begin{abstract}
Fig. 4. Analysis of the segment of a chimeric whiG gene in pRHB596. (a) Homology between the nucleotide sequence of the chimeric whiG gene from pRHB596 (whiGX) and the corresponding whiG sequence of $S$. roseosporus (SrwhiG) and $S$. coelicolor (ScwhiG). (b) Homology between the predicted amino acid sequence of the chimeric $\sigma^{\text {whiG }}$ (whiGX) and the corresponding amino acid sequence of $S$. roseosporus $\sigma^{\text {whiG }}$ (Srwhig) and S. coelicolor $\sigma^{\text {whig }}$ (ScwhiG). Nucleotide and amino acids with shading indicate identity with the corresponding chimeric sequence. Nucleotide and amino acid positions are indicated to the right of the corresponding sequences.
\end{abstract}

genes is functional in each strain. It is possible that both are functional, but somewhat more heat labile than the native GSI because of the chimeric structures. Further work is needed to clarify this point.

The whiG gene encodes a sigma factor $\sigma^{w h i G}$ required for sporulation in $S$. coelicolor (Chater et al., 1989) and in $S$. roseosporus (T. Hosted \& R. H. Baltz, unpublished). The
whiG gene is found in single copy in $S$. coelicolor and in other sporulating actinomycetes (Chater et al., 1989; Soliveri et al., 1993). We tested three recombinants, TH503D, TH503E and TH503F, containing pRHB503 inserted into the chromosome within the whiG gene, for sporulation on B agar. All produced normal amounts of aerial mycelium and spores, suggesting that at least one of the chimeric whiG genes is functional in each strain. 
Table 3. GS activity in S. roseosporus strains

\begin{tabular}{|lccc|}
\hline \multirow{2}{*}{ Strain } & GS & \multicolumn{2}{c|}{ GS specific activity (units) } \\
\cline { 3 - 4 } & & Without heat treatment & With heat treatment* \\
& & $8 \cdot 8$ & $8 \cdot 5$ \\
TH104 & Wild-type & $10 \cdot 2$ & $7 \cdot 5$ \\
TH131 & Wild-type & $19 \cdot 0$ & $6 \cdot 1$ \\
TH104G1 & Chimeric & $18 \cdot 4$ & $9 \cdot 8$ \\
TH104G2 & Chimeric & $0 \cdot 0$ & $0 \cdot 0$ \\
TH161 & GSI-defective &
\end{tabular}

* Cells were incubated at $57^{\circ} \mathrm{C}$ for 30 min prior to determining GS activity.

\section{DISCUSSION}

The $e b r$ mutants isolated in the present study from a library of Tn5099-10 mutants did not appear to be caused by transposition mutations based upon sequence analysis of DNA flanking four different Tn5099-10 inserts. However, the selection for $e b r$ mutants by demanding homeologous recombination between the $S$. coelicolor glk gene in KC570 and the $S$. roseosporus glk gene to obtain $\mathrm{Ts}^{\mathbf{R}}$ transductants was successful. We confirmed that many different mutants expressed the Ehr phenotype by carrying out recombinational tests in two other genes, $g \ln A$ and $w h i G$. The $e b r$ mutants generally showed $10^{2}$ - to $10^{4}$ fold higher frequencies of recombination within these partially homologous genes, but did not show elevated homologous recombination. Somewhat surprisingly, the ehr mutants did not express a spontaneous mutator phenotype. This differs from the mut $L$ and mut $S$ genes in $S$. typhimurium and E. coli, which express elevated spontaneous mutation rates as well as enhanced homeologous recombination. On the other hand, Saccbaromyces cerevisiae has multiple mutS homologues that seem to have diverged in function (Hollingsworth et al., 1995; New et al., 1993; Reenan \& Kolodner, 1992; Selva et al., 1995; Strand et al., 1995). Mutations in the $S$. cerevisiae MSH3 gene do not affect the rate of spontaneous mutation at several loci (Strand et al., 1995), but cause enhanced homeologous recombination (Selva et al., 1995). The ebr gene(s) in Streptomyces roseosporus may encode functions homologous or analogous to that provided by the $M S H 3$ gene in $S$. cerevisiae. The molecular cloning of $S$. roseosporus ebr gene(s) should shed light on this question.

Regardless of the precise function of the $e h r$ gene(s), the ebr mutations caused enhanced homeologous recombination in frame and in proper translational register within the $g \ln A$ and $w h i G$ structural genes, as confirmed by DNA sequence analysis. Furthermore, recombinants containing the hybrid whiG genes sporulated and recombinants containing hybrid $g \ln A$ genes produced functional GS activity. It is known from studies in $S$. coelicolor that the whiG gene encodes a sigma factor required for sporulation (Chater et al., 1989). The whiG gene in $S$. roseosporus is also required for sporulation ( $T$. Hosted \& R. Baltz, unpublished). Since the recombination of the $S$. coelicolor whiG gene with the $S$. roseosporus whiG gene appears to have occurred by a triple crossover within a span of about 200 base pairs, presumably generating two hybrid (mosaic) genes, at least one of the hybrid genes must encode a functional $\sigma^{\text {whiG }}$. The recombinants containing two hybrid $g \ln A$ genes produced GS activities at about twice the amount produced by the control strains before heat treatment and activities approximately equal to controls after heat treatment. Since GSI is a dodecameric enzyme arranged as two rings stacked on top of one another (Almassy et al., 1986), recombinants containing two hybrid $g \ln A$ genes may produce two different chimeric GSI subunits which in turn form mixed dodecameric structures. This suggests that both chimeric subunits may be active, and that the decreased heat stability may be due to the chimeric nature of the subunits.

These results suggest that $e b r$ mutants may be useful for several applications. The ehr mutants can be used to generate hybrid genes and hybrid proteins at high frequencies in vivo. This provides a means to carry out protein engineering in vivo, and might provide a means to carry out recombination within related modular sequences found in type I polyketide synthase genes (Katz \& Donadio, 1993; Schwecke et al., 1995) and in peptide synthetase genes (Turgay et al., 1992; von Döhren et al., 1993; Stachelhaus et al., 1995) to produce novel structures. The ehr mutants also provide an efficient means to insert known genes into partially homologous genes, facilitating physical mapping, gene disruption and cloning of related genes. Finally, ebr mutants may facilitate general recombination between diverse species of Streptomyces to enhance product yields or to produce novel secondary metabolites. The latter application has been demonstrated using conventional recombination techniques (Gomi et al., 1984; Schlegel \& Fleck, 1980).

\section{ACKNOWLEDGEMENTS}

We thank S. Fisher for providing the $S$. coelicolor $g \ln A$ gene, $\mathrm{K}$. Chater for providing the $S$. coelicolor whiG gene and KC570 phage, S. Burgett, P. Rockey and P. Rosteck for DNA sequence analysis, P. Solenberg for preparing transposition mutant libraries, B. Fogleman for typing the manuscript, and Eli Lilly and Company for supporting the work. T. Hosted was supported as a Lilly Postdoctoral Fellow. 


\section{REFERENCES}

Almassy, R. J., Janson, C. A., Hamlin, R., Xuong, N.-H. \& Eisenberg, D. (1986). Novel subunit-subunit interactions in the structure of glutamine synthetase. Nature 232, 304-309.

Altschul, S. F., Gish, W., Miller, W., Myers, E. W. \& Lipman, D. J. (1990). Basic local alignment search tool. J Mol Biol 215, 403-410.

Baltz, R. H. (1978). Genetic recombination in Streptomyces fradiae by protoplast fusion and cell regeneration. J Gen Microbiol 107, 93-102.

Baltz, R. H. \& Matsushima, P. (1983). Advances in protoplast fusion and transformation in Streptomyces. Experientia 46, 143-148.

Behrmann, I., Hillermann, D., Puhler, A., Strauch, E. \& Wohlleben, W. (1990). Overexpression of a Streptomyces viridochromogenes gene ( $g \ln I I)$ encoding a glutamine synthetase similar to those of eucaryotes confers resistance against the antibiotic phosphinothricyl-alanyl-alanine. J Bacteriol 172, 5326-5334.

Bender, R. A., Janssen, K. A., Resnick, A. D., Blumenberg, M., Foor, F. \& Magasanik, B. (1977). Biochemical parameters of glutamine synthetase from Klebsiella aerogenes. J Bacteriol 129, 1001-1009.

Bierman, M., Logan, R., O'Brien, K., Seno, E. T., Rao, N. \& Schoner, B. E. (1992). Plasmid cloning vectors for the conjugal transfer of DNA from Escherichia coli to Streptomyces spp. Gene 116, 43-49.

Chater, K. F. \& Bruton, C. J. (1983). Mutational cloning in Streptomyces and the isolation of antibiotic production genes. Gene 26, 67-78.

Chater, K. F. \& Hopwood, D. A. (1983). Streptomyces genetics. In The Biology of the Actinomycetes, pp. 229-286. Edited by M. Goodfellow, M. Mordarski \& S. T. Williams. London: Academic Press.

Chater, K. F., Bruton, C. J., Plaskitt, K. A., Buttner, M. J., Mendez, C. \& Helmann, J. D. (1989). The developmental fate of S. coelicolor hyphae depends upon a gene product homologous with the motility $\sigma$ factor of B. subtilis. Cell 59, 133-143.

Claverys, J. P. \& Lacks, S. A. (1986). Heteroduplex deoxyribonucleic acid base mismatch repair in bacteria. Microbiol Rev 50, 133-135.

Cleaver, J. E. (1994). It was a very good year for DNA repair. Cell 76, 1-4.

Cox, K. L. \& Baltz, R. H. (1984). Restriction of bacteriophage plaque formation in Streptomyces spp. J Bacteriol 159, 499-504.

Devereux, J., Haeberli, P. \& Smithies, O. (1984). A comprehensive set of sequence analysis programs for the VAX. Nucleic Acids Res 12, 387-395.

von Döhren, H., Pfeifer, E., van Liempt, H., Lee, Y.-O., PavelaVrancic, M. \& Schwecke, T. (1993). The nonribosomal system: what we learn from the genes encoding protein templates. In Industrial Microorganisms: Basic and Applied Molecular Genetics, pp. 159-167. Edited by R. H. Baltz, G. D. Hegeman \& P. L. Skatrud. Washington, DC: American Society for Microbiology.

Feinstein, S. I. \& Low, K. B. (1986). Hyper-recombining recipient strains in bacterial conjugation. Genetics 113, 13-33.

Fishel, R., Lescoe, M. K., Rao, M. R. S., Copeland, N. G., Jenkins, N. A., Garber, J., Kane, M. \& Kolodner, R. (1993). The human mutator gene homolog $\mathrm{MSH} 2$ and its association with hereditary nonpolyposis colon cancer. Cell 75, 1027-1038.

Fisher, S. H. \& Wray, L. V. (1989). Regulation of glutamine synthetase in Streptomyces coelicolor. J Bacteriol 171, 2378-2383.

Fisher, S. H., Bruton, C. J. \& Chater, K. F. (1987). The glucose kinase gene of Streptomyces coelicolor and its use in selecting spontaneous deletions for desired regions of the genome. Mol Gen Genet 206, 35-44.
Gomi, S., Ikeda, D., Nakamura, H., Naganawa, H., Yamashita, F., Hotta, K., Kondo, S., Okami, Y. \& Umezawa, H. (1984). Isolation and structure of a new antibiotic, indolizomycin, produced by a strain SK2-52 obtained by interspecies fusion treatment. J Antibiot 37, 1491-1494.

Hollingsworth, N. M., Ponte, L. \& Halsey, C. (1995). MSH5, a novel mut $S$ homologue, facilitates meiotic reciprocal recombination between homologs in Saccharomyces cerevisiae but not mismatch repair. Genes Dev 9, 1728-1739.

Hopwood, D. A., Bibb, M. J., Chater, K. F., Kieser, T., Bruton, C. J., Kieser, H. M., Lydiate, D. J., Smith, C. P., Ward, J. M. \& Schrempf, H. (1985). Genetic Manipulation of Streptomyces: a Laboratory Manual. Norwich: John Innes Foundation.

Katz, L. \& Donadio, S. (1993). Polyketide synthesis: prospects for hybrid antibiotics. Annu Rev Microbiol 47, 875-912.

Kumada, Y., Takano, E., Nagaoka, K. \& Thompson, C. J. (1990). Streptomyces bygroscopicus has two glutamine synthase genes. $J$ Bacteriol 172, 5343-5351.

Le, O., Shen, B., lismaa, S. E. \& Burgess, B. K. (1993). Azotobacter vinelandii mut $S$ : nucleotide sequence and mutant analysis. J Bacteriol 175, 7707-7710.

Lomovskaya, N. D., Voeykova, T. A. \& Mkrtumian, N. M. (1977). Construction and properties of hybrids obtained in interspecies crosses between Streptomyces coelicolor A3(2) and Streptomyces griseus Kr.15. J Gen Microbiol 98, 187-198.

Matic, I., Radman, M. \& Rayssiguier, C. (1994). Structure of recombinants from conjugational crosses between Eschericbia coli donor and mismatch-repair deficient Salmonella typhimurium recipients. Genetics 136, 17-26.

Mazieres, N., Peyre, M. \& Penasse, L. (1981). Interspecific recombination among aminoglycoside producing streptomycetes. $J$ Antibiot 34, 544-550.

New, L., Liu, K. \& Crouse, G. F. (1993). The yeast gene MSH3 defines a new class of eukaryotic mutS homologues. Mol Gen Genet 239, 97-108.

Penyige, A., Kálmáncyhelyi, A., Sipos, A., Ensign, J. C. \& Barabás, G. (1994). Modification of glutamine synthetase in Streptomyces griseus by ADP-ribosylation and adenylation. Biochem Biopbys Res Commun 204, 598-605.

Rayssiguier, C., Thaler, D. S. \& Radman, M. (1989). The barrier to recombination between Eschericbia coli and Salmonella typhimurium is disrupted in mismatch-repair mutants. Nature 342, 396-401.

Reenan, R. A. G. \& Kolodner, R. D. (1992). Isolation and characterization of two Saccharomyces cerevisiae genes encoding homologs of the bacterial HexA and MutS mismatch repair proteins. Genetics 132, 963-973.

Sambrook, J., Fritsch, E. F. \& Maniatis, T. (1989). Molecular Cloning: a Laboratory Manual, 2nd edn. Cold Spring Harbor, NY: Cold Spring Harbor Laboratory.

Schlegel, B. \& Fleck, W. F. (1980). New anthracycline antibiotics produced by interspecific recombinants of streptomycetes. $Z$ Allg Mikrobiol 20, 527-530.

Schwecke, T., Aparicio, J. F., Molnár, I., König, A., Khaw, L. E., Haydock, S. F., Oliynyk, M., Caffrey, P., Cortés, J., Lester, J. B., Bobhrn, G. A., Staunton, J. \& Leadlay, P. F. (1995). The biosynthetic gene cluster for the polyketide immunosuppresant rapamycin. Proc Natl Acad Sci USA 92, 7839-7843.

Selva, E. M., New, L., Crouse, G. F. \& Lahue, R. S. (1995). Mismatch correction acts as a barrier to homeologous recombination in Saccharomyces cerevisiae. Genetics 139, 1175-1188. 
Simon, R., Preifer, U. \& Pühler, A. (1983). A broad host range mobilization system for in vivo genetic engineering: transposon mutagenesis in Gram negative bacteria. Bio/Tecbnology 1, 784-791.

Solenberg, P. J. \& Baltz, R. H. (1991). Transposition of $\operatorname{Tn} 5096$ and other IS493 derivatives in Streptomyces griseofuscus. J Bacteriol 173, 1096-1104.

Solenberg, P. J. \& Baltz, R. H. (1994). Hypertransposing derivatives of the streptomycete insertion sequence IS493. Gene 147, 47-54.

Soliveri, J., Vijgenbook, E., Cranozzi, C., Plaskitt, K. A. \& Chater, K. F. (1993). Functional and evolutionary implications of a survey of various actinomycetes for homologues of two Streptomyces coelicolor sporulation genes. J Gen Microbiol 139, 2569-2578.

Speyer, J. F. (1990). A simple and effective electroporation apparatus. Biotechniques $8,28-31$.

Stachelhaus, T., Schneider, A. \& Marahiel, M. A. (1995). Rational design of peptide antibiotics by targeted replacement of bacterial and fungal domains. Science 269, 69-72.

Strand, M., Earley, M. C., Crouse, G. F. \& Petes, T. D. (1995). Mutations in the $M S H 3$ gene preferentially lead to deletions within tracts of simple repetitive DNA in Saccharomyces cerevisiae. Proc Natl Acad Sci US A 92, 10418-10421.

Turgay, K., Krauss, M. \& Marahiel, M. A. (1992). Four homologous domains in the primary structure of $\mathrm{GrsB}$ are related to domains in a superfamily of adenylate-forming enzymes. Mol Microbiol 6, 2743-2744.

Worth, L., Clark, S., Radman, M. \& Modrich, P. (1994). Mismatch repair proteins MutS and MutL inhibit RecA-catalyzed strand transfer betwen diverged DNAs. Proc Natl Acad Sci USA 91, 3238-3241.

Wray, L. V., Jr \& Fisher, S. H. (1988). Cloning and nucleotide sequence of the Streptomyces coelicolor gene encoding glutamine synthetase. Gene 71, 247-256.

Zahrt, T. C., Mora, G. C. \& Maloy, S. (1994). Inactivation of mismatch repair overcomes the barrier to transduction between Salmonella typhimurium and Salmonella typhi. J Bacteriol 176, 1527-1529.

Received 19 February 1996; revised 21 May 1996; accepted 4 June 1996. 